\title{
Frekuensi Menonton Pemberitaan Televisi tentang Kematian Akibat COVID-19 Berkontribusi pada Kecemasan Mahasiswa di Kota Tangerang
}

\section{Frequency of Watching Television News about Deaths Due to COVID-19 Contributes to Student Anxiety in Tangerang City}

\author{
Rustono Farady Marta ${ }^{1, *)}$, Timotius Saliman ${ }^{1}$, Helena Elmydea Shinta ${ }^{2}$, Fiolita Desyana ${ }^{2}$, Mufid Salim $^{3}$
}

${ }^{1}$ Universitas Bunda Mulia Kampus Ancol, 021-6909090, Jln. Lodan Raya No.2, Ancol, Jakarta Utara, 14430

${ }^{2}$ Universitas Bunda Mulia Kampus Serpong, 021-80821428, Jln. Jalur Sutera Barat Kav 7-9 Alam Sutera, Tangerang, 15143

${ }^{3}$ Universitas Ahmad Dahlan, 0274-563515, Jln. Kapas No.9, Semaki, Yogyakarta, 55166

*)E-mail : rmarta@bundamulia.ac.id

Diterima: 4 Februari 2022 || Disetujui: 28 Februari 2022 | Publikasi online: 7 Maret 2022

\begin{abstract}
This study deals with the widespread news of deaths due to COVID-19 on television to measure its impact. The purpose of this study was to determine the contribution of the intensity of the frequency of watching news broadcasts on deaths due to COVID-19 on television on the anxiety level of Tangerang city students. This research uses a positivistic paradigm with a survey method involving the reliability of network technology facilitated by Google Form. This research involves a number of detailed analyzes, starting from the Validity and Reliability Test of the research instrument, then continued with the Normality Test, Heteroscedasticity Test, and ends with the T Test. The results of this study indicate that there is a level of anxiety due to the spectacle of news of death due to COVID-19 with a fairly high frequency. In line with the Hypodermic Needle Theory and Cultivation Theory, which show the great power of television media, the intensive audience can imagine that it is actually happening to ourselves and/or those closest to us. The research results which contained 93 respondents indicate that COVID-19 information spread through television is affecting students in Tangerang significantly with their anxiety level. This result is in line with the mass number of students who are still using television as their source of information with approximately $81,7 \%$ of the respondents. The research result is also correlated with the prominent position of television in the digital convergence era as a primary source of information to Indonesia citizens.
\end{abstract}

Kata kunci: Cultivation theory, COVID-19, Hypodermic needle Theory, News, Television

\section{ABSTRAK}

Penelitian ini berkenaan dengan maraknya pemberitaan kematian akibat COVID-19 di televisi untuk diukur dampaknya dalam menciptakan kecemasan pada kalangan mahasiswa di Kota Tangerang dalam melakukan berbagai aktivitas kesehariannya. Tujuan penelitian ini untuk mengetahui kontribusi dari intensitas frekuensi menonton tayangan pemberitaan kematian akibat COVID-19 di televisi pada tingkat kecemasan mahasiswa kota Tangerang. Metode penelitian ini menggunakan paradigma positivistik dengan metode survei kepada mahasiswa Kota Tangerang. Penelitian ini dilakukan melibatkan sejumlah analisis terperinci, mulai dari pengujian validitas dan reliabilitas instrumen riset, kemudian dilanjutkan dengan uji normalitas, uji heteroskedastisitas, hingga diakhiri dengan uji t. Hasil penelitian ini menunjukkan bahwa adanya tingkat kecemasan akibat tontonan pemberitaan kematian akibat COVID-19 dengan frekuensi yang cukup sering. Sejalan dengan Hypodermic Needle Theory bahwa media massa mempunyai kekuatan yang sangat besar dalam membentuk perubahan perilaku manusia. Didukung pula Teori Kultivasi yang memandang bahwa semakin lama menonton televisi maka khalayaknya dapat membayangkan berita di televisi menjadi senyata-nyatanya terjadi pada diri dan/atau sekeliling terdekat kita. Hasil penelitian yang mendapati 93 responden menunjukkan bahwa paparan informasi COVID-19 yang didistribusi dari televisi mampu memberikan pengaruh yang signifikan kepada tingkat kecemasan mahasiswa Tangerang. Temuan ini sejalan dengan masih banyaknya mahasiswa Tangerang yang menggunakan televisi sebagai sarana penerimaan informasi dengan jumlah $81,7 \%$ dari seluruh responden. Korelasi penelitian ini tampak dari posisi televisi yang masih prominen di era konvergensi digital sebagai salah satu pusat distributor informasi bagi masyarakat Indonesia.

Kata kunci: Berita, COVID-19, Teori Jarum Suntik, Teori Kultivasi, Televisi

Content from this work may be used under the terms of the Creative Commons Attribution-ShareAlike 4.0 International. Any further distribution of this work must maintain attribution to the author(s) and the title of the work, journal citation and DOI.

Published under Department of Communication and Community Development Science, IPB University and in association with Forum Komunikasi Pembangunan Indonesia and Asosiasi Penerbitan Jurnal Komunikasi Indonesia.

E-ISSN: 2442-4102 | P-ISSN: 1693-3699 


\section{PENDAHULUAN}

Perkembangan teknologi di setiap masa semakin berkembang pesat, salah satunya televisi. Medium yang awalnya menjadi media utama bagi masyarakat untuk menerima informasi telah beradaptasi dengan perubahan zaman mengikuti teknologi kekinian. Urgensi penggunaan telepon seluler tidak dipungkiri mengubah gaya hidup manusia, namun tidak melemahkan posisi televisi dalam menyebarkan informasi kepada orang banyak. Digitalisasi televisi mencairkan posisi televisi di tengah maraknya telefon pintar digital yang mempertahankan podium televisi sebagai salah satu pusat distributor informasi (Briandana et al., 2020). Akselerasi teknologi juga mencairkan sejumlah komunikasi massa melalui konektifitas internet. Komunikasi massa yang semakin ketat dalam dunia digital membutuhkan strategi yang mendetail dari komunikator untuk menyampaikan isi pesan kepada komunikan (Harry et al., 2021). Komunikasi massa menurut pendapat DeFleur \& McQuail merupakan suatu proses penyebarluasan berbagai pesan secara luas melalui media tertentu dan beragam cara agar tercipta macam-macam makna di benak khalayak pembaca, penonton, dan/atau pendengarnya secara berkesinambungan yang ditujukan untuk memberi pengaruh cukup besar (Mendayun \& Sjuchro, 2019).

Zaman konvergensi digital yang menyebar secara global masih belum dapat menggapai semua orang, seperti orang-orang yang tinggal di pedesaan dimana mereka masih menggunakan televisi sebagai sumber informasi dan juga hiburan. Wilayah yang tidak dapat dicapai teknologi tak lain didasari oleh kesiapan warga lokal dan sumber daya yang memadai (Yusriyah et al., 2020). Tidak semua pedesaan atau tempat-tempat di luar kota-kota besar memiliki sinyal internet yang bagus. Banyak pedesaan yang masih belum terjangkau oleh sinyal internet sehingga tidak semuanya dapat menggunakan ataupun mengakses telepon selulur untuk mendapatkan infomasi atau berita dengan cepat. Permasalahan tersebut membuat media konvensional masih bertahan ditengah transformasi digitalisasi Indonesia (Krzywdzinski, 2020).

Berdasarkan artikel kompas.com masih banyak masyarakat yang percaya bahwa televisi telah menjadi salah satu sumber mereka dalam mendapatkan dan mencari informasi atau berita di luar sana. Sebanyak $89 \%$ masyarakat menggunakan televisi dan mepercayai permberitaan yang ada di televisi (Kompas, 2020). Hal ini juga disebabkan banyaknya informasi atau berita yang disebarkan di internet membuat masyarakat bingung dengan mana berita yang sebenarnya dan mana berita bohong yang disiarkan oleh internet.

Habibie (2018) dalam penelitian ini menjelaskan bahwa adanya komunikasi media massa televisi dengan khalayak. Media massa acapkali digunakan sebagai alat atau sarana yang digunakan manusia, utamanya khalayak besar untuk menyampaikan dan mendapatkan pesan atau informasi. Masyarakat memanfaatkan dan menggunakan media massa sebagai sarana untuk menyampaikan dan mendapatkan informasi. Media massa dibagi menjadi 2 klasifikasi, yaitu: media cetak seperti buletin, koran, tabloid, majalah, dll; dan media elektronik atau media penyiaran seperti radio dan televisi. Kini televisi banyak berperan sebagai penengah antara media digital dengan konvensional sebagai komunikasi massa yang masih digunakan masyarakat (Adi Nugraha \& Rizar Nugroho, 2021).

Yudhaswara (2021) menemukan banyak sajian program di televisi khususnya dengan program pemberitaan tentang pandemi COVID-19. Hal tersebut membuat masyarakat memiliki kebebasan untuk memilih dan menerima konteks pandemi yang ditayangkan di media konvensional tersebut. Banyak stasiun televisi yang memberitakan tentang COVID-19 khususnya pada kematian yang diakibatkan oleh virus ini membuat khalayak khususnya mahasiswa di Kota Tangerang Provinsi Banten memiliki wawasan yang lebih luas lagi terhadap bahaya dan dampaknya COVID-19 ini hingga menyebabkan ribuan kasus kematian.

Pandemi yang terjadi di Indonesia ini disebabkan oleh adanya wabah virus corona atau banyak disebut dengan singkatan "COVID-19". Tingkat penyebaran serta kematian yang tinggi melahirkan kecemasan tersendiri bagi masyarakat yang sering beraktifitas diluar (Septiarysa et al., 2021). Pandemi yang mendunia setelah ditemukan pada November 2019 memaksa semua orang untuk membatasi aktifitas eksternal dan memanfaatkan digitalisasi teknologi untuk melanjutkan kegiatan sehari-hari. Susilo (2020) mencerminkan konvergensi di kala pandemi COVID-19 di Indonesia. Awal mulanya sekolah dan perkuliahan hanya diliburkan selama dua minggu, dan kini sistem pembelajaran dilakukan serba daring. Penyebaran COVID-19 di Indonesia membuat banyak masyarakat Indonesia takut secara berlebihan dalam situasi tersebut.Setiap hari perkembangan mengenai orang yang terjangkit, yang meninggal, dan yang dinyatakan sembuh dari virus ini terus diberitakan dimana-mana. Baik di media 
online, berita online, koran, televisi, dll. ini dilakukan untuk memberitahukan kepada masyarakat mengenai info terbaru tentang virus ini (Marta et al., 2021). Peliputan yang menyampaikan pesan kepada nusantara secara tidak langsung melahirkan fobia yang berhujung kepada kepanikan dalam masyarakat.

Pemberitaan mengenai menyebarnya virus corona dan informasi mengenai COVID-19 ini disiarkan lewat media televisi. Sebagai salah satu media massa yang cukup populer di Indonesia, televisi memberi informasi kepada masyarakat Indonesia mengenai wabah virus ini yang masuk pertama kali ke Indonesia pada awal Maret 2020. Semenjak itu, media televisi mulai menyebarkan berbagai kabar mengenai virus corona ini. Mulai dari beberapa banyak orang yang terjangkit virus ini, cara pemerintah akan menyikapi masalah serius ini, bahkan sampai memberi informasikan mengenai jumlah kematian yang disebabkan oleh virus ini.

Selain untuk menginformasikan mengenai virus COVID-19 ini, media televisi juga sebagai sarana penghubung antara pemerintah dengan masyarakat. Media televisi menyampaikan pesan-pesan dari pemerintah untuk masyarakat contohnya seperti (1) menginformasikan akan penderitaan COVID-19 di Indonesia bahkan di dunia; (2) mengapresiasi masyarakat yang terus bersama mengajak orang lain tetap di rumah; (3) mengingatkan agar masyarakat Indonesia bisa mematuhi kebijakan yang sudah dibuat oleh pemerintah. Mulai dari semua kegiatan dilakukan secara online (sekolah, kulaih, kerja, ibadah,dll) atau sering disebut Work From Home (WFH) kemudian melakukan pembatasan sosial di tempat umum, mematuhi protokol kesehatan dengan slalu menggunakan masker, membawa hand sanitizer, dll.

Menurut Siahaan (2020), WFH (work from home) diadakan oleh pemerintah untuk menekan kasus positif dan kematian yang diakibatkan oleh COVID-19. Banyaknya masyarakat yang melakukan work from home atau berkegiatan dari rumah membuat stasiun televisi harus dapat menyediakan kebutuhan khalayak dari mulai informasi, hiburan, bahkan pendidikan yang harus di siarkan televisi. Pada saat ini televisi sudah menjadi bagian yang sudah tidak bisa dipisahkan dari kehidupan manusia. Banyak masyarakat yang menghabiskan waktu di depan televisi untuk menonton program yang ditayangkan oleh media televisi. Hal tersebut dilakukan untuk memenuhi kebutuhan masyarakat akan informasi ataupun hanya sebatas memenuhi kebutuhan hiburan dirinya (Rosfiantika et al., 2020). Media telvisi sekarang menayangkan berbagai tayangan program seperti kuis, infotainment, serial, sinetron, musik, dan lain-lain.

Ada beberapa stasiun televisi, peneliti melakukan klasifiasi stasiun televisi sesuai genre, antara lain: (1) Televisi Hiburan : RCTI, SCTV, TransTv, ANTV, Trans7, MNC Group; (2) Televisi Pendidikan : TVRI, dan (3) Televisi berita : TVone, MetroTv, KompasTv,CNN Indonesia. Menurut sumber Reuters Institute, 25 November 2021. Stasiun yang paling banyak menjadi sumber berita di Indonesia semasa pandemic adalah sebagai berikut:

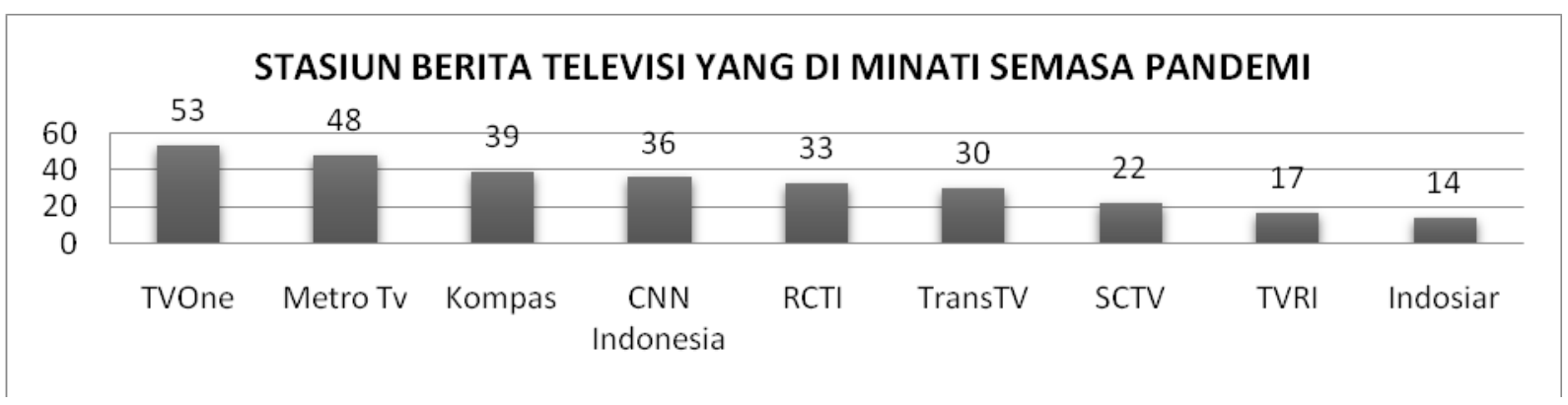

Gambar 1. Sumber : databoks, Reuters Institute.

Berdasarkan riset yang dilakukan oleh Reuters Institute pada 25 November 2021 bahwa semasa pandemik masyarakat Indonesia memilih menonton berita COVID-19 dan berita lainnya di stasiun TVOne. Berangkat dari jumlah presentase terbanyak, bahwa 53\% responden yang mengaku bahwa TVOne merupakan salah satu sumber berita yang paling diminati di televisi.

Keunggulan yang lebih diperoleh dari televisi dibanding media elektronik lainnya yaitu radio. Televisi punya visual dan audio di dalamnya, yang mana ketika seseorang menonton televisi akan memudahkan penonton untuk mendapatkan bayangan atau imajinasi dari informasi atau berita yang ditayangkan. Televisi bisa memberikan hiburan kepada penontonnya dengan menyajikan programprogram yang menarik, jadi tidak hanya sebagai pemberi informasi atau berita ke masyarakat tetapi 
televisi juga bisa memberikan hiburan ke penontonnya. Televisi seringkali digunakan sebagai alat propaganda seperti yang diuraikan pada Teori Jarum Suntik merupakan teori yang muncul setelah melihat adanya keberhasilan pola propaganda tersebut, karena dalam teori jarum suntik ini khalayak tidak memiliki kekuatan yang besar untuk menghindar atau menolak "tembakanan atau suntikan" lewat media komunikasi (Sampurno et al., 2020).

Menurut teori jarum suntik atau yang sering disebut hypodermic needle theory merupakan sebuah teori yang dimana khalayak tidak memiliki kekuatan untuk menolak informasi yang ditayangkan oleh media televisi sehingga mengakibatkan para masyarakat seperti dibius oleh media, masyarakat dikontrol dengan apa yang dilihat dan ditonton oleh media televisi tentang bagaimana mereka menjalani kehidupan mereka di dunia nyata. Mehrad (2020) menjelaskan realitas yang ditransformasi oleh komunikasi media, baik digital maupun konvensional. Teori jarum suntik juga mengatakan bahwa khalayak tidak bisa menghindar dari apa yang sudah disuntik/ditembak oleh media komunikasi. Khalayak akan terlena seperti kemasukan obat bius lewat jarus suntik, sehingga khalayak tidak dapat memiliki akses untuk memilih hal yang lain, kecuali apa yang disiarkan/disuntikan oleh media tersebut. Lebih lanjut, khalayak juga bisa dimanipulasi atau dibohongi dengan berbagai cara yang sudah dimanipulasi oleh media itu sendiri.

Pada dasarnya teori jarum suntik ini adalah one step flow atau aliran satu arah. Asumsi yang ada pada teori ini adalah komponen komunikasi yang ada amat sangat kuat dalam mempengaruhi komunikasi. Teori jarum suntik ini sepandan dengan teori stimulus-respon, karenateori jarum suntik ini menjelaskan tentang "menyuntik atau menembakan" isi pesan kepada pemikiran audiens (stimulus) sehingga audiens bertindak atas pemikiran tersebut (respon). Kurniawan (2018) menjelaskan teori stimulus-respon sebagai korelasi antara pesan media yang disampaikan dengan reaksi atau respon dari si penerima. Asumsi teori S-R ini adalah pesan dalam segala bentuk baik secara non verbal atau verbal akan mengakibatkan respon dari si penerima. Gerak yang dihasilkan oleh penonton ini adalah gerak otomatis atau gerak reflex, yang dimana ketika disuntikan atau ditembak oleh teori jarum suntik akan menimbulkan respon dari penonton. Terdapat dua sumber pemikiran dari konsep teori jarum suntik ini, yaitu: pihak televisi (penyelenggara) memiliki kekuatan dan lebih pintar dari komunikan untuk mengelabuhi para komunikannya melalui isi pesan media yang ditembakannya secara langsung melalui channel televisi dan komunikasi ketika menerima isi pesan yang disampaikan oleh televisi langsung terlena dalam ketidak sadarannya mengkonsumsi isi pesan televisi sehingga menyebabkan perubah tingkah laku.

Thompson (2014) mengungkapkan teori kultivasi sebagai efek dari penayangan stasiun televisi yang dikonsumsi setiap harinya dapat mempengaruhi pola pikir. Terciptanya pola pikir baru tentang kehidupan di sekitar khalayak, serta mempercayai isi pesan televisi tersebut. Teori ini menanamkan stigma tentang dunia seperti yang ada di tayangan televisi tersebut. Menurut Marta (2016) menjelaskan analisis kultivasi ditempatkan sebagai suatu tahap lanjutan berupa cultural indicators dari riset efek media massa oleh Gerbner, yang menyelidiki tiga hal berikut: (1) proses institusional dalam proses produksi isi pesan dalam media; (2) image atau kesan yang tampak dari isi media kepada khalayak; kemudian (3) keterkaitan antara munculnya terpaan pesan televisi dengan penciptaan keyakinan serta perilaku khalayak.

Teori kultivasi menjelaskan bahwa ada dua jenis tipe penonton yaitu heavy viewers (penonton berat) yang merupakan tipe penonton dengan frekuensi yang lama hingga berjam-jam perharinya sehingga sudah mengalami kecanduan dan meyakinkan secara berlebihan isi media televisi dan membuat mereka berpikir bahwa yang diberitakan media akan terjadi di dunia nyatanya. Hal ini membuat sang penonton mengalami ketakutan bahwa dunia adalah tempat yang berbahaya. Tipe kedua adalah light viewers (penonton ringan) yaitu seseorang yang menonton televisi namun hanya terbatas tontonan yang mereka pilih dan tidak membayangkan bahwa dunia akan semenakutkan yang diperlihatkan di media televisi.

Terdapat keterkaitan antara teori jarum suntik dengan teori kultivasi. Teori jarum suntik adalah sebuah konsep yang mana penontonnya atau khalayaknya seperti disuntik dan mereka tidak bisa menghindar dari suntikan tersebut. Audiens tidak punya kekuatan untuk menghindar dari suntikan tersebut. Hal ini berkaitan erat dengan teori kultivasi yang mana teori ini menjelaskan bahwa jika khalayak terus menonton televisi dengan waktu yang lama akan mempengaruhi sikap atau perilaku dan bahkan pola pikir dari audiens tersebut, sehingga menyebabkan orang yang menonton menjadi yakin bahwa dunia luar itu menakutkan. 
Teori Manajemen Kecemasan dan Ketidakpastian (Anxiety and Uncertainty Theory/AUM) yang dikembangkan oleh Gudykunst sebagai pengembangan dari Teori Pengurangan Ketidakpastian (Uncertainty Reduction Theory/ URT) dari Berger dan Calabrese (1975) menjelaskan bahwa teori manajemen kecemasan ini bahwa orang asing adalah orang yang tidak kita kenal yang berada dalam lingkungan yang tidak mengenalnya. Menurut teori ini, kecemasan manuasia dalam situasi sosial mempengaruhi manajemen kecemasan dirinya sehingga mereka cenderung merasa tidak aman dan tidak yakin saat bersikap. Kecemasan yang dialami oleh khalayak terkait dengan rasa cemas dan khawatir karena memiliki informasi yang dapat membuat dirinya merasa tidak aman sehingga mereka merasakan bahwa tingkat kecemasan diri mereka juga meningkat setelah mendengar informasi dari televisi terkait dengan kematian akibat COVID-19 di Indonesia (Campbell-Salome et al., 2021).

Berdasarkan tinjauan pustaka yang berisi teori-teori yang berhubungan dengan media massa televisi. Penelitian ini juga memiliki tujuan penelitian, yaitu: (1) untuk mengetahui pengaruh frekuensi tayangan pemberitaan kematian COVID-19 di televisi terhadap tingkat kecemasan mahasiswa di kota Tangerang; (2) mengetahui dampak yang dialami ketika menonton pemberitaan (Nasrullah \& Sulaiman, 2021) COVID-19 di televisi terlalu lama; dan (3) mengetahui keterkaitan teori jarum suntik dengan teori kultivasi di kehidupan masyarakat.

Penelitian yang dilakukan Aan Daryanto (2018) menggunakan variabel X pengaruh tayangan program berita 86 di NetTV, bahwa Semakin sering tayangan program berita 86 di NET TV akan mempengaruhi kecemasan orang tua di RW 07 Kelurahan Tugu, Cimanggis, Kota Depok (Edi, 2014). Berdasarkan latar belakang yang telah diuraikan, maka permasalahan penelitian ini terkait dampak frekuensi menonton televisi mahasiswa terhadap tingkat kecemasaan mereka saat mengetahui banyaknya informasi bahkan kematian tentang COVID-19 ini, khususnya di Kota Tangerang. Permasalahan penelitian berangkat dari hipotesis bahwa pesan yang dikirimkan komunikator di media televisi yang dapat membius (berdampak) pada kecemasan khalayak mahasiswa penonton akan sebuah fenomena pemberitaan kematian akibat COVID-19 tersebut. Permasalahan ini membuat penulis melakukan survei kepada beberapa mahasiswa di wilayah Tangerang yang terpengaruh frekuensi menonton pemberitaan kematian COVID-19 di televisi berkontribusi pada tingkat kecemasannya atau tidak.

\section{METODE PENELITIAN}

Penelitian ini melibatkan mahasiswa-mahasiswi yang berkuliah di Kota Tangerang Provinsi Banten, menggunakan pendekatan kuantitatif yang fokus terhadap kuantitas data terkumpul dengan berlandaskan pada filsafat positivisme, digunakan untuk mengukur atau meneliti sampel atau populasi tertentu (Utama et al., 2021). Paradigma postivisme digunakan dalam penelitian ini, menurut Auguste Comtepada abad ke-19 paradigma penelitian positivisme ini ditujukan sebagai langkah verifikasi suatu masalah melalui pengamatan rinci di lingkungan sekitar. Positivistik menempatkan ilmu sebagai metode untuk membuktikan sebuah fenomena kehidupan melalui pengamatan deduktif (Hidayat et al., 2019). Penelitian ini ditujukan untuk mengetahui bahwa menonton televisi dengan frekuensi yang lama atau sebentar tentang penanyangan berita kematian COVID-19 akan mempengaruhi tingkat kecemasan responden (Rosfiantika et al., 2020).

Analisis data kuantitatif yang digunakan adalah statistik inferensial atau yang dikenal dengan statstik induktif dengan analisis korelasional. Statistik inferensial adalah analisis data yang mengambil sampel dari populasi yang jumlahnya banyak (Zebuah, 2018), sementara analisis korelasional adalah sebuah metode analisis data kuantitatif statistik induktif dengan mencari pengaruh atau hubungan dari dua variabel, kedua variabel tersebut adalah variabel terikat $(\mathrm{Y})$ dan variabel bebas (X). Tulisan ini akan menjabarkan variabel X sebagai frekuensi menonton pemberitaan kematian COVID-19 di media televisi. Pemilihan variabel ini didasari oleh dimensi stimulus yang dikirim oleh televisi dengan indikator durasi penayangan dan konteks pesan. Reaksi dari khalayak akan diukur melalui stimulus eksternal yang mengubah atau membentuk sebuah perilaku.

Variabel Y yang digunakan dalam penelitian ini mencakup tingkat kecemasan mahasiswa di Kota Tangerang dengan dimensi penonton televisi secara berkala. Khalayak yang dikaji dalam penelitian ini didasari generasi muda yang berperan sebagai penerus kelangsungan bangsa (Ahmad et al., 2019). Lebih lanjut, heavy viewers dapat membawa dampak buruk pagi perilaku, psikologis, hingga kepada tingkat kecemasan seseorang. Selanjutnya, perubahan perilaku juga dapat disebabkan oleh tingginya tingkat kecemasan dalam kehidupan sseorang atau tingginya kecanduan yang mereka alami tentang suatu tayangan, Tingkat kecemasan, heavy viewers, dan perubahan perilaku mahasiswa di Kota 
Tangerang akan menjadi tolak ukur dalam variabel dependen yang digambarkan dalam kerangka pemikiran penelitian ini sebagai berikut: Penelitian ini memiliki variabel independen berupa Frekuensi Pemberitaan Kematian COVID-19 yang mempengaruhi Tingkat Kecemasan Mahasiswa di Kota Tangerang sebagai variabel dependen. Adapun hipotesis dalam penelitian terjabar sebagai berikut:

H1: Frekuensi Menonton pemberitaan Kematian COVID-19 mempengaruhi Tingkat Kecemasan Mahasiswa Kota Tangerang Ha: Frekuensi Pemberitaan Kematian COVID-19 tidak mempengaruhi Tingkat Kecemasan Mahasiswa Kota Tangerang

Peneliti menggunakan metode survei dengan membuat kuesioner menggunakan skala Likert. Instrumen kuesioner ini menggunakan formulir Google yang kemudian disebarluaskan melalui media sosial seperti Instagram, Line, dan Whatsapp kepada 93 mahasiswa semester lima sebagai sampel dari total populasi Mahasiswa di Kota Tangerang dengan menggunakan incidental random samplingdi Kota Tangerang Provinsi Banten (Pelupessy \& Yanuar, 2020). Pemilihan mahasiswa sebagai sampel penelitian dilatarbelakangi oleh pemahaman mahasiswa akan akselerasi teknologi dan kemampuan mereka dalam beradaptasi dengan perubahan zaman. Utama (2021) mendefinisikan skala likert sebagai sekumpulan pertanyaan deklaratif yang diberikan kepada para responden untuk memberikan pendapat mereka setuju atau tidak terhadap pernyataan tersebut. Skala likert yang peneliti gunakan dalam penelitian ini dengan rentangan 1-4 mulai dari sangat tidak setuju, tidak setuju, setuju, dan sangat setuju. Peneliti menghilangkan sebuah rentangan di tengah untuk pernyataan ragu-ragu, agar tidak menyulitkan proses interpretasi peneliti terhadap kecenderungan jawaban yang diberikan responden.

\section{HASIL DAN PEMBAHASAN}

Televisi memiliki karakteristik yang dapat menarik khalayak serta memenuhi kebutuhan khalayak. Konteks peliputan informasi dari televisi dapat direpresentasikan melalui penghlihatan dan pendengaran khalayak yang memiliki keunggulan dari media konvensional lainnya (Lumampauw et al., 2021). Kelengkapan validitas informasi melalui gambar dan suara memberikan semiotika yang lebih bermakna kepada khalayak televisi. Jangkauan khalayak televisi yang luas juga membantu kelangsungan televisi di tengah konvergensi digital. Pengiriman informasi komunikator sangat dibantu oleh media televisi yang menjangkau masyarakat banyak dengan tenggat waktu yang sedikit (Akbar et al., 2018). Proses penerjemahan informasi yang diterima melalui televisi juga merangsang pola pikir khalayak. Rangkaian gambar dapat dipersepsi secara terpisah dan memiliki banyak makna didalam sebuah adegan (Harry et al., 2021). Setiap komunikator televisi harus memperhatikan sisi budaya khalayak selaku penerima informasi televisi.

Televisi ini merupakan media yang sangat unik dan berbeda dari media lainnya. Televisi memiliki kekuatan atau power yang sangat kuat sehingga dapat membentuk pola pikir atau cara berpikir masyarakat yang menoton televisi. Semakin sering menonton televisi atau menghabiskan waktu yang lama untuk menonton televisi akan membuat penonton menjadi kecenderungan dalam menyamakan realitas yang ada di televisi dengan yang ada di kehidupan sebenarnya. Thompson (2014) menjelaskan asumsi-asumsi yang ada pada teori kultivasi antara lain: (1) media televisi ini dapat dikatakan media yang sangat unik; (2) khalayak menjadi sulit membedakan realita dengan imaji visual yang ditampilkan media televisi; (3) polarisasi penonton media televisi dua jenis tipe khalayak: (4) Intensitas penyampaian informasi merubah pola pikir penontonnya; dan (5) televisi membentuk mainstreaming dan resonance.

Pertama, dapat katakan unik karena karakteristik dari televisi yang dapat diakses tanpa dituntut adanya kemampuan atau keahlian lainnya, hampir dimiliki oleh seluruh keluarga juga menampilkan pesan dengan dasar pemikiran yang serupa. Kedua, semakin sering menghabiskan waktu untuk menonton televisi atau menonton televisi dengan jangka waktu yang lama, akan membuat penonton atau khalayak menjadi sulit membedakan dan akan semakin sering menyamakan realita dunia dengan realita yang ditampilkan atau disajikan televisi. Di sisi lain, bagi heavy viewer akan menyatakan bahwa dunia ini lebih kejam dibandingkan kenyataan yang sebenarnya terjadi. Ketiga, terdapat dua jenis tipe penonton televisi, yaitu light viewer yang lebih cenderung menggunakan media yang lebih bervariasi dalam mencari atau mendapatkan informasi, sedangkan heavy viewer lebih mengandalkan televisi sebagai sumber informasi mereka. Teori kultivasi ini memiliki pengaruh yang kuat terhadap perilaku dan sikap dari penontonnya. Keempat, terpaan pesan media yang dilakukan secara terus menerus atau intens seperti yang dilakukan oleh televisi dalam menyampaikan berita atau informasi dapat membuat pola pikir penontonya berubah. Penonton televisi akan berpikir bahwa apa yang 
ditampilkan televisi adalah gambaran dunia yang sebenarnya, dunia yang kejam. Pembentukan mainstreaming dan resonance oleh televisi, yang dimaksud dengan mainstreaming berupa suatu kemampuan untuk menyeragamkan berbagai pandangan yang terdapat di masyarakat tentang hal yang terjadi di dunia. Selanjutnya, resonance berimplikasi padaefek pesan media dalam membentuk persepsi realita tertentu yang tersaji di media televisi serupadengan peristiwa di kehidupan nyata.

Dalam rangka memecahkan permasalahan penelitian ini, maka ditempuh pembagian kuesioner sejak Hari Kamis, 24 Desember 2021 hingga Hari Selasa 1 Febuari 2022 secara daring menjelaskan bahwa ada tingkat kecemasan yang berubah saat mahasiswa menonton tayangan pemberitaan kematian COVID-19.Adapun jumlah responden yang diperolehberada pada rata-rata usia 20 tahun, yaitu sejumlah $44,1 \%$ dari hasil responden dan usia 21 tahun dengan jumlah persentase $25,9 \%$ dan sisanya sekitar usia 22 tahun keatas. Responden ini rata-rata berjenis kelamin prempuan yaitu sebanyak $68,8 \%$ dan sisanya laki-laki. Ini merupakan tahapan awal untuk mengetahui data responden penelitian ini.

Dalam teori jarum suntik yang menjelaskan tentang efek dari isi media yang ditembakan secara langsung kepada otak khalayak sehingga khalayak tidak memiliki kekuatan untuk menolak isi media televisi. Dari hasil distribusi jawaban responden mahasiswa yang menjawab bahwa ada $44.1 \%$ dan $37,6 \%$ yang masih sering menonton televisi, artinya $81,7 \%$ berpotensi menonton pemberitaan COVID19 yang disiarkan oleh televisi .Hal tersebut masih menunjukan bahwa televisi masih memiliki kekuatan untuk mendapatkan khalayak di masa pandemi, juga di zaman yang sudah serba mengandalkan teknologi utamanya internet ini. Mereka masih mempercayai televisi sebagai salah satu pedoman untuk menonton pemberitaan COVID-19 di Indonesia seperti diilustrasikan pada Gambar 2.

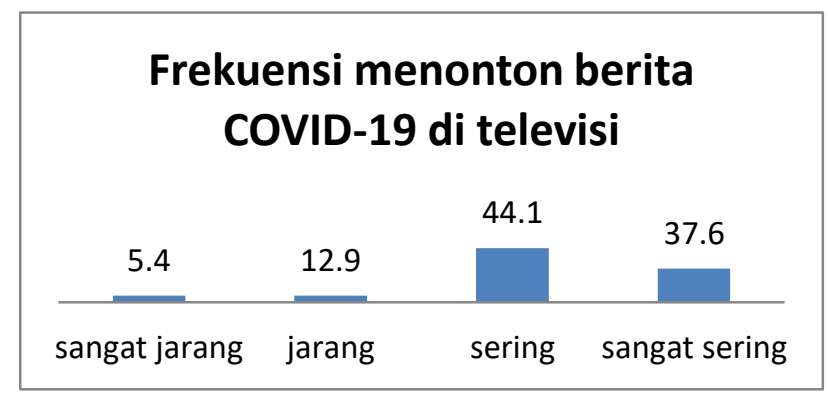

Gambar 2. Jumlah Responden yang Menonton Berita Pandemi COVID-19 di Televisi. Sumber: Olahan Peneliti

Sebelumnya televisi dari awal tahun 2020 hingga sampai dengan awal tahun 2021 setiap harinya memberitakan perkembangan kasus COVID-19 yang ada, kasus COVID-19 yang sering diberitakan adalah tentang angka positif COVID-19 yang tinggi serta tingkat kematian yang tinggi. Hal ini menyebabkan khalayak yang menonton pemberitaan tersebut menjadi gelisah bahkan cemas dengan virus ini. Kecemasan merupakan kondisi atau emosi negatif yang menguasai diri atau merupakan respon tubuh dari keadaan yang mendesaknya sehingga memberikan perasaan yang gelisah atau tidak tenang.Dalam penelitian ini kecemasan akibat menonton pemberitaan memberikan efek yang negatif namun juga memberikan efek yang positif.

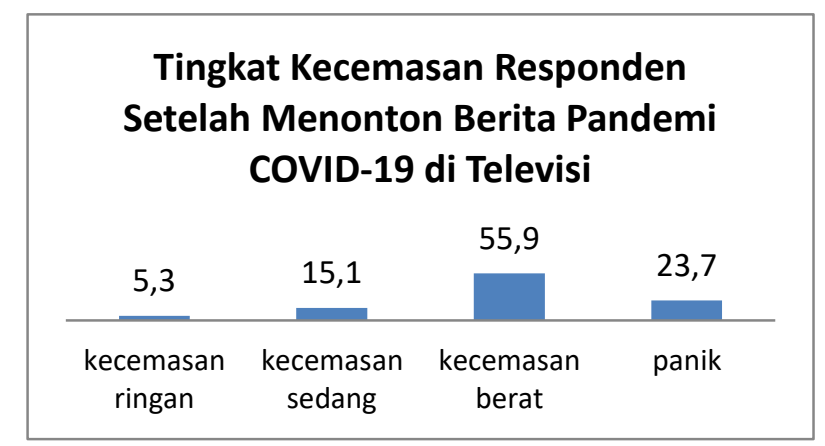

Gambar 3. Tingkat Kecemasan Responden Setelah Menonton Berita Pandemi COVID-19 di Televisi. Sumber: Hasil Penelitian 2021.

Terlihat bahwa 79.6\% dari jawaban responden penelitian ini memberikan tanggapan bahwa adanya pemberitaan kematian COVID-19 di televisi membuat tingkat kecemasan berat hingga panik mereka 
menjadi meningkat. Sebanyak $20.4 \%$ dari jawaban responden memberikan tanggapan bahwa mereka masih ada di tingkat kecemasan ringan hingga sedang saja. Kemudian dari pernyataan lainnya mereka memberikan respon kecemasan mereka meningkat mengakibatkan mereka jarang berinteraksi diluar rumah, kalaupun mereka keluar rumah mereka harus menggunakan masker, hand sanitizer, serta harus pedulit terhadap kebersihan lingkungan mereka. Efek negatif yang ditimbulkan oleh media pemberitaan kematian COVID-19 adalah membawa efek kecemasan yang berlebih, membuat orang takut untuk melakukan kegiatannya, dan membuat orang panik karena membayangkan bahwa virus ini dapat merenggut nyawanya. Di sisi lain, menonton pemberitaan kematian akibat COVID-19 juga memberikan efek positif yang ditimbulkan yaitu memberi wawasan yang luas lagi tentang penyebab kematian atau gejala COVID-19 yang dapat merenggut nyawa.

Gustinerz (2021) menyimpulkan empat tingkat kecemasan. Tingkatan pertama diawali oleh kecemasan ringan yang awam terjadi di kehidupan sehari-hari dan merangsang kewaspadaan orang yang mengalami kecemasan tersebut. Perubahan fokus kehidupan orang terhadap hal yang penting namun mengabaikan aspek kehidupan lain memberikan tingkatan kedua berupa kecemasan berat. Kecemasan tingkat berat mengakibatkan individu kehilangan kendali atas keputusan hidupnya. Bantuan dari pihak eksternal sangat dibutuhkan dalam kasus ini. Tingkatan tertinggi dalam kecemasan berada pada kondisi panik dimana individu atau kelompok memiliki rasa khawatir yang berlebihan. Perilaku ini secara tidak langsung mengubah perilaku dan mengacaukan pola pikir dari individu atau kelompok yang panik. Setiap tingkat kecemasan memiliki faktor penyebab yang berbeda-beda. Penyebab kecemasan ini bisa dari faktor media televisi, media online, maupun media-media offline. Peneliti menggunakan bantuan SPSS untuk mengukur uji validitas dan reliabilitas penelitian ini. Berikut hasil perhitungan dari data-data yang sudah dicek dari SPSS.

\section{Uji Validitas}

Uji Validitas menurut Supriadi (2017), validitas berhubungan dengan suatu peubah mengukur apa yang seharusnya diukur. Pengujian validitas ini dilakukan untuk mengetahui apakah pernyatanpernyatan yang ada pada kuesioner salah atau tidak. Dan dapat dikatakan validitas merupakan aspek kecermaatan pengukuran dalam menjalankan fungsi ukurnya.

Uji validitas ini digunakan untuk mengetahui kevalidan yang ada pada kuesioner yang sudah dibagikan dalam pengumpulan data. Untuk memudahkan penulis dalam menguji validitas ini. Penulis menggunakan rumus korelasi bivariate pearson dengan bantuan dari program applikasi SPSS versi 22.0 dan juga Microsoft Excel dan Google Spreadsheet. Setiap kuesioner akan dinyatakan valid jika $\mathrm{r}$ hitung > $\mathrm{r}$ tabel pada nilai sig (5\%) (Widi, 2011). Dan sebaliknya, jika $r$ hitung $<\mathrm{r}$ tabel maka akan dinyatakan tidak valid. Dan berikut hasil data yang diperoleh dari uji validitas yang ada pada tabel berikut:

Tabel 1. Hasil Uji Validitas

\begin{tabular}{|c|c|c|c|c|c|c|c|}
\hline Var. & Rhitung & Rtabel & Keterangan & Var. & Rhitung & Rtabel & Keterangan \\
\hline X1 & 0,682 & 0,202 & Valid & Y1 & 0,793 & 0,202 & Valid \\
\hline X2 & 0,628 & 0,202 & Valid & Y2 & 0,842 & 0,202 & Valid \\
\hline X3 & 0,717 & 0,202 & Valid & Y3 & 0,843 & 0,202 & Valid \\
\hline X4 & 0,757 & 0,202 & Valid & Y4 & 0,852 & 0,202 & Valid \\
\hline X5 & 0,808 & 0,202 & Valid & Y5 & 0,660 & 0,202 & Valid \\
\hline X6 & 0,794 & 0,202 & Valid & Y6 & 0,710 & 0,202 & Valid \\
\hline X7 & 0,765 & 0,202 & Valid & Y7 & 0,629 & 0,202 & Valid \\
\hline X1 & 0,682 & 0,202 & Valid & Y8 & 0,586 & 0,202 & Valid \\
\hline
\end{tabular}

Sumber: Olahan Peneliti

Hasil perhitungan uji validasi sebagaimana yang tertera di tabel atas, dapat dikatakan bawah di setiap pernyataan yang ada pada kuesioner yang disebar $r$ hitung $>r$ tabel.Seperti di indicator $X 1$, nilai $r$ hitung dari X1 adalah 0,682 dan hasil tersebut lebih besar dari $r$ tabel. Jika ditulis jadinya seperti 0,682 $>\mathrm{r}$ tabel.Karna hasil $\mathrm{r}$ hitung dari X1 $(0,682)$ lebih besar dari $\mathrm{r}$ tabel, maka pernyataan 1 dari varibel $\mathrm{X}$ itu valid. Begitu juga dengan hasil dari pernyataan 1 dari varibel $\mathrm{Y}$ dengan hasil 0,793 $>\mathrm{r}$ tabel, sehingga pernyataan tersebut valid. Dan itu berlaku untuk semua pernyataan yang ada pada varibel $\mathrm{X}$ dan Y karna hasil perhitungan dari app SPSS versi 22.0 menyatakan $r$ hitung $>r$ tabel. 


\section{Uji Reliabilitas}

Menurut Riduwan (2010:) hasil dari uji reliabilitas pada suatu instrumen penelitian kuantitatif dapat menggunakan rumus Cronbach's Alpha. Cronbach's Alpha, karena ditujukan secara khusus untuk mengetahui tingkat reliabilitas ukuran, yang mana sebuah instrument riset dapat dikatakan reliabel bila memiliki koefisien keandalan atau yang dilambangkan dengan alpha hingga lebih dari angka 0,6.

Uji reliabilitas ini menggunakan rumus alpha menggunakan taraf uji 0,05 (Perdana, 2021). Dapat dikatakan reliabel jika $\mathrm{r}$ alpha $>\mathrm{r}$ hitung, begitu juga sebaliknya. Jika $\mathrm{r}$ alpha $<\mathrm{r}$ hitung, maka pernyataan tersebut dinyatakan tidak reliabel. Dalam rangka memudahkan perhitungan penulis dalam menguji reliabilitas ini, penulis menggunakan bantuan program SPSS 22.0 dan Microsoft Excel dan juga Google Spreadsheet.

Tabel 2. Hasil Uji Reliabilitas

\begin{tabular}{|c|c|}
\hline Cronbach's Alpha & Variabel \\
\hline 0,849 & $\mathrm{X}$ \\
\hline 0,882 & $\mathrm{Y}$ \\
\hline
\end{tabular}

Sumber: Olahan Peneliti

Dari tabel 2 di atas hasil uji reliablitas pada variabel $X$ (pengaruh frekuensi menonton pemberitaan kematian akibat COVID-19 di televisi) dengan hasil 0.849>0.202 dinyatakan bahwa pernyataan yang ada pada kuesioner $\mathrm{X}$ dinyatakan reliabel. Tabel Y dengan hasil (tingkat kecemasan mahasiswa/i semester 5 universitas bunda mulia) dengan hasil 0.882>0.202 dinyatakan bahwa pernyataan yang ada pada kuesioner Y dinyatakan reliabel.

Terkait dengan hasil perhitungan uji reliabilitas, diperoleh nilai koefisien reliabilitas dari kuesioner untuk Variabel X dengan hasil 0,849sementara Variabel Y dengan hasil 0,882. Berdasarkan hasil tersebut dapat diinterpretasikan bahwa nilai koefisien reliabilitas baik kuesioner Variebel $\mathrm{X}$ dan kuesioner Variebel $\mathrm{Y}$ dinyatakan reliabel karna $\mathrm{r}$ alpha $>\mathrm{r}$ hitung. Oleh karena itu, dapat dikatakan bahwa frekuensi menonton pemberitaan kematian akibat COVID-19 di televisi (Variebel X) berkontribusi pada tingkat kecemasan (Variabel Y) dinyatakan reliable dan konsisten karena nilai cronbach's alpha $>$ r hitung.

\section{Uji Normalitas}

Selain menguji validitas dan reliabilitas dari penelitian ini, peneliti juga menguji normalitas. Uji normalitas ini bertujuan untuk mengetahui apak sampel yang diambil adalah data yang berdistribusi normal atau tidak. Pada pengujian ini uji normalitas melalu uji One Sample Kolmogorov-Smirnov. Jika nilai Asymp.Sig > 0,05 maka varibel dianggap normal. Namun sebaliknya jika Asymp.Sig < 0,05 maka variable tersebut dinyatakan tidak normal (Saliman et al., 2021).

Tabel 3. Hasil Uji Normalitas

\begin{tabular}{|c|c|}
\hline & Unstandardized Residual \\
\hline Asymp.Sig. (2-tailed) & 0,200 \\
\hline
\end{tabular}

Sumber: Olahan Peneliti

Dan hasil dari perhitungan yang dihitung peneliti dengan bantuan app SPSS versi 22.0 mengenai uji normalitas yang ada pada kuesioner yang disebar adalah (tabel 3). Dapat dinyatakan bahwa data yang disebar normal. Ini dikarenakan hasil dari uji normalitas yang ada lebih besar dari 0,05 . Hasil uji normalitas pada data ini adalah 0,200. Hasil uji normalitas $0,200>0,05$. Oleh karena itu, dapat dinyatakan bahwa data terdistribusi secara normal.

\section{Uji Heteroskedastisitas}

Pada tahap ini, peneliti menguji heteroskedastisitas guna untuk mengetahui apakah adanya ketidaksamaan varian residual untuk semua pengamatan pada model regresi. Sebaiknya regresi tidak terjadi heteroskedastisitas (Dewi \& Hidayat, 2014). Pada perhitungan ini, peneliti menggunakan uji scatterplot. Yang mana scatterplot ini berbentuk gambar (tabel 6): 


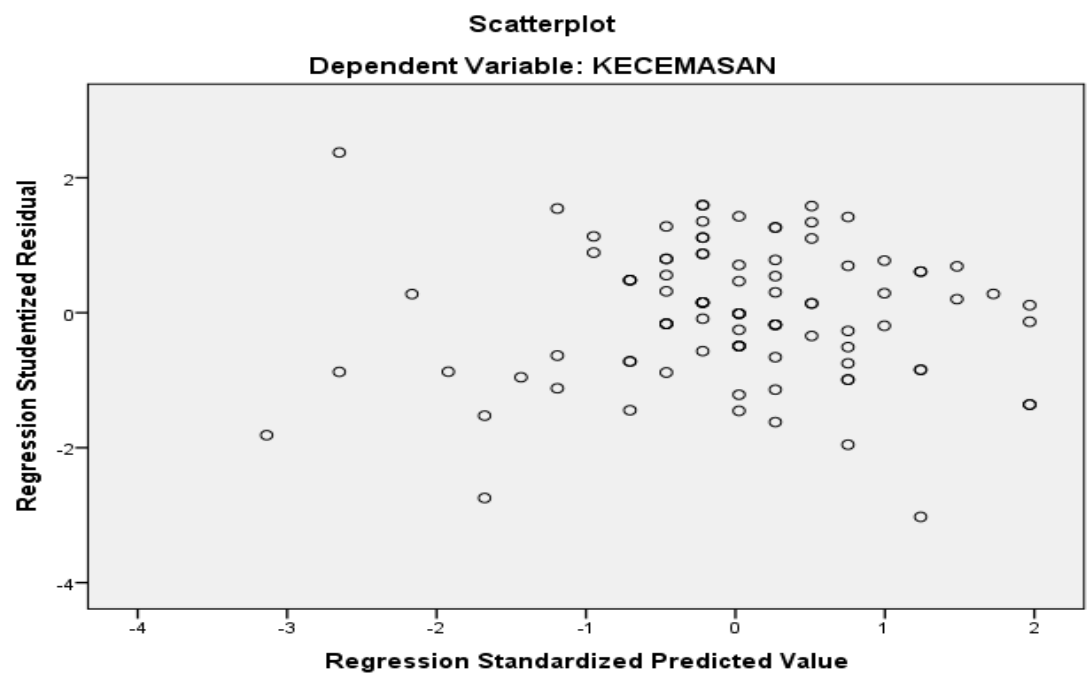

Gambar 4. Hasil Uji Scatterplot. Sumber: Olahan Peneliti

Berdasarkan gambar 4 dapat diinterpretasikan bahwa data yang ada tersebut tidak terjadi heteroskedastisitas, karena di dalam uji scatterplot: (1) titik-titik data nampak menyebar tidak membentuk pola tertentu, melainkan titik tersebut berada di atas dan di bawah atau di sekitar angka 0; (2) titik-titik tidak terpolarisasi menjadi terkumpul hanya berada di bagian atas atau sebaliknya, di bagian bawah saja; dan (3) tidak membentuk suatu pola apapun, termasuk pola gelombang melebar kemudian cenderung menyempit dan melebar kembali, karena nampak bahwa titik-titik tersebut menyebar.

\section{Uji Hipotesis}

Pada tahapan yang terakhir dalam penelitian ini, peneliti menguji uji t. Pengujian ini bertujuan untuk melihat frekuensi menonton pemberitaan kematian akibat COVID-19 di televisi (Variabel X) berkontribusi pada tingkat kecemasan mahasiswa yang ada di daerah Tangerang (Variabel Y). Uji T ini dilakukan untuk menguji pengaruh setiap variable babas terhadap varibel terikat (Purwanto, 2019).

Tabel 4. Hasil Uji T

\begin{tabular}{|c|c|c|c|}
\hline \multicolumn{4}{|c|}{ Coefficients } \\
\hline \multicolumn{2}{|c|}{ Model } & t & Sig. \\
\hline 1 & (Constant) & 4,792 & 0,000 \\
\cline { 2 - 4 } \multicolumn{2}{|c|}{ Frekuensi } & 6,468 & 0,000 \\
\hline \multicolumn{3}{|c|}{ a. Dependent Variabel: Kecemasan } \\
\hline
\end{tabular}

Sumber: Olahan Peneliti

Saliman (2021) menyebutkan data penelitian berpengaruh jika nilai $t$ hitung $>t$ tabel. Data juga akan dinyatakan tidak berpengaruh jika $t$ hitung $<$ dari $t$ tabel. Berdasarkan hasil dari perhitungan peneliti dengan bantuan SPSS, Uji T pada penelitian ini menunjukkan hasil 6,468. Angka 6,468 berada di atas angkat T hitung 1,661 (Kilonzo et al., 2018), sehingga dapat diinterpretasikan bahwa variabel X berupa frekuensi menonton pemberitaan kematian akibat COVID-19 di televisi memberi kontribusi positif dan signifikan pada variabel $\mathrm{Y}$, yaitu tingkat kecemasan mahasiswa yang ada di daerah Tangerang.

Informasi dan edukasi yang diberikan televisi sebagai media komunikasi konvensional masih dapat diterima oleh masyarakat global. Aktifitas dunia dicerminkan oleh liputan televisi kepada seluruh belahan dunia (Gunawan, 2020). Konten televisi memberikan pengetahuan kepada khalayak akan berbagai aktifitas hidup. Televisi tidak dipungkiri punya peran yang sangat penting dalam menyampaikan berita kepada masyarakat luas, sehingga kebutuhan akan menonton televisi meningkat semenjak ada nya pandemi di tahun 2020. Berdasarkan temuan ini, penulis menemukan bahwa 
konteks informasi dalam televisi dapat mempengaruhi perilaku khalayak yang menvalidasi hipotesis frekuensi pemberitaan jumlah kematian COVID-19 dapat mempengaruhi tingkat kecemasan mahasiswa di Kota Tangerang. Popularitas televisi yang masih relevan ditengah era digitalisasi menjadi temuan khusus dimana masyarakat masih menonton televisi sebagai sarana penerimaan informasi. Kepercayaan masyarakat akan televisi juga mendukung bertahannya popularitas televisi ditengah telefon pintar yang naik daun.

\section{KESIMPULAN}

Berangkat dari pembahasan untuk hasil penelitian dapat disimpulkan bahwa adanya keterkaitan erat antara teori jarum suntik dengan teori kultivasi. Teori jarum suntik memiliki kekuatan dalam media komunikasi dan dapat mempengaruhi pola pikir penonton yang sedang menonton. Hal ini dikarenakan dalam teori jarum suntik memiliki komponen stimulus-respon, maka ketika penonton sedang menonton tayangan televisi (stimulus) dan penonton tersebut memberikan respon, kemudian menonton televisi dengan frekuensi yang lama akan mempengaruhi pola pikir penonton sesuai dengan bunyi teori kultivasi.

Berdasarkan pernyataan-pernyataan yang tercantum dalam kuesioner dapat diketahui bahwa adanya tingkat kecemasan yang dimiliki oleh mahasiswa yang ada di daerah Tangerang. Tingkat kecemasan yang dimiliki oleh mahasiswa yang ada di daerah Tangerang ini merupakan pengaruh dari frekuensi menonton pemberitaan kematian COVID-19 di televisi. Sedikitnya 81,7\% responden yang menyatakan bahwa mereka sering melihat televisi dan berpotensi melihat tayangan pemberitaan kematian akibat COVID-19 di televisi, isi pesan yang disampaikan berita mudah diserap sehingga penting untuk dijadikan catatan bagi pengelola televisi khususnya konten berita untuk memperhatikan konten yang disiarkan. Utamanya berkaitan dengan pemberitaan kematian akibat COVID-19 di televisi sebaiknya berupa "penyambung lidah" saja untuk Tim Satuan Petugas (SatGas) COVID-19 pada tingkat Nasional sebagai informasi penyerta atau running text, yang tidak secara khusus ditampilkan dalam segmen acara atau berita terpisah agar tidak menyebabkan tingginya tingkat kecemasan khalayaknya.

\section{DAFTAR PUSTAKA}

Adi Nugraha, Y., \& Rizar Nugroho, D. (2021). Does Television Promote Deagrarianization? Understanding Rural-Youth Perception Towards the Agricultural-livelihood information on Television. Jurnal Komunikasi Pembangunan, 19(01), 27-37. https://doi.org/10.46937/19202133714

Ahmad, T., Alvi, A., \& Ittefaq, M. (2019). The Use of Social Media on Political Participation Among University Students: An Analysis of Survey Results From Rural Pakistan. SAGE Open, 9(3), 215824401986448. https://doi.org/10.1177/2158244019864484

Akbar, K. M., Hanief, L., \& Alif, M. (2018). Semangat Nasionalisme dalam Film (Analisis Isi Kuantitatif dalam Film Merah Putih). ProTVF: Jurnal Kajian Televisi Dan Film. https://doi.org/10.24198/ptvf.v1i2.19872

Briandana, R., Pribadi, E., \& Balaya, S. (2020). Mapping the Convergence Trends of Television Broadcasting Media in Indonesia. Bricolage : Jurnal Magister Ilmu Komunikasi, 6(02), 147. https://doi.org/10.30813/bricolage.v6i02.2120

Campbell-Salome, G., Buchanan, A. H., Hallquist, M. L. G., Rahm, A. K., Rocha, H., \& Sturm, A. C. (2021). Uncertainty management for individuals with Lynch Syndrome: Identifying and responding to healthcare barriers. Patient Education and Counseling, 104(2), 403-412. https://doi.org/10.1016/j.pec.2020.07.017

Dewi, S. P., \& Hidayat, R. (2014). Pengaruh Net Profit Margin dan Return on Assets terhadap Harga Saham pada Perusahaan Otomotif yang Terdaftar di Bursa Efek Indonesia. Ilman.

Edi, A. (2014). Pengaruh Media Televisi Terhadap Prilaku Remaja Di Desa Gedongan Kota Gede Yogyakarta. Angewandte Chemie International Edition, 6(11), 951-952., 5-24.

Gunawan, R. H. (2020). Saluran Komunikasi Politik dalam Pembangunan Demokrasi pada Pemilu Legislatif DPR-RI di Kota Bogor 2019. Jurnal Komunikasi Pembangunan, 18(02), 141-151. https://doi.org/10.46937/18202031350

Gustinerz. (2021). Yuk Kenali, 4 Tingkat Kecemasan - Gustinerz.com. Gustinerz. 
Habibie, D. K. (2018). Dwi Fungsi Media Massa. Interaksi: Jurnal Ilmu Komunikasi, 7(2), 79. https://doi.org/10.14710/interaksi.7.2.79-86

Harry, H., Marta, R. F., \& Briandana, R. (2021). Memetakan Tautan Budaya Lasem melalui Dokumenter Net . Biro Jawa Tengah dan MetroTVNews. ProTVF, 5(2), 227-246. https://doi.org/https://doi.org/10.24198/ptvf.v5i2.33411

Hidayat, D., Rosidah, Z., Retnasary, M., \& Suhadi, M. (2019). Nilai-nilai kearifan lokal pada unsur naratif dan sinematik film Jelita Sejuba. ProTVF, 3(2), 113. https://doi.org/10.24198/ptvf.v3i2.21264

Kilonzo, T. M., Were, S., \& Odhiambo, R. (2018). Influence of employee engagement on the performance of teachers in secondary schools in Machakos County in Kenya. International Journal of Novel Research in Humanity and Social Sciences, 5(1), 52-71.

Kompas. (2020). KPI: 89 Persen Masyarakat Lebih Percaya Televisi Dibanding Internet. Kompas.Com.

Krzywdzinski, M. (2020). Automation, Digitalization, and Changes in Occupational Structures in the Automobile Industry in Germany, the United States, and Japan. A Brief History from the Early 1990s Until 2018, 10, 68.

Kurniawan, D. (2018). Komunikasi Model Laswell dan Stimulus-Organism-Response dalam Mewujudkan Pembelajaran Menyenangkan. Jurnal Komunikasi Pendidikan, 2(1), 60. https://doi.org/10.32585/jkp.v2i1.65

Lumampauw, A., Marta, R. F., Nugroho, Y., Sandel, T. L., \& Lie, S. (2021). The art of honing the conscience through bukalapak ads : barongsai Indonesia , juara hati membangun bangsa. International Journal of Visual and Performing Arts, 3(1), 9-21. https://doi.org/https://doi.org/10.31763/viperarts.v3i1.342

Marta, R. F., \& Monica William, D. (2016). Studi Terpaan Media Pemasaran Melalui Posting Instagram Terhadap Ekuitas Merek Pelanggan Sumoboo! Jurnal Komunikasi Untar. https://doi.org/http://dx.doi.org/10.24912/jk.v8i1.50

Marta, R. F., Syarnubi, K. L., Wang, C., Cahyanto, I. P., Briandana, R., \& Isnaini, M. (2021). Gaining public support: Framing of esports news content in the COVID-19 pandemic. SEARCH Journal of Media and Communication Research, 13 no. 2(2), 71-86.

Mehrad, J., Eftekhar, Z., \& Goltaji, M. (2020). Vaccinating Users Against the Hypodermic Needle Theory of Social Media: Libraries and Improving Media Literacy. International Journal of Information Science and Management, 18(1), 17-24.

Mendayun, I., \& Sjuchro, D. W. (2019). Efek Komunikasi Massa Program Citizen Report Di Radio PRFM Bandung. Jurnal Kajian Jurnalisme, 2(1), 98. https://doi.org/10.24198/jkj.v2i1.21320

Nasrullah, \& Sulaiman, L. (2021). Analisis Pengaruh COVID-19 Terhadap Kesehatan Mental Masyarakat di Indonesia. Media Kesehatan Masyarakat Indonesia, 20(3), 206-211.

Pelupessy, A. G., \& Yanuar. (2020). Pengaruh Facilitating Conditions dan Social Influences terhadap Konstruk Technologi Acceptance Model pada Mahasiswa Konsumen Gopay dan OVO di Jakarta. Jurnal Manajemen Bisnis Dan Kewirausahaan, 4(6), 328-333. https://doi.org/http://dx.doi.org/10.24912/jmbk.v4i6.9835

Perdana, K. E. (2021). Analisa Model Komunikasi Lasswell Pada Halaman “@aswaja_sunda” Dalam Turut Mempertahankan Ajaran Islam Ahlussunnah Wal Jamaah di Media Instagram. The International Journal of Pegon : Islam Nusantara Civilization, 5(01), 25-38. https://doi.org/10.51925/inc.v5i01.47

Purwanto. (2019). Analisis Korelasi dan Regresi Liner dengan SPSS 21 (Panduan Praktis untuk Penelitian Ekonomi Syariah). StaiaPress.

Rosfiantika, E., Permana, R. S. M., \& Mahameruaji, J. N. (2020). Program live update pemberitaan risiko Covid-19 di televisi nasional Indonesia. ProTVF: Jurnal Kajian Televisi Dan Film, 4(2), 247. https://doi.org/10.24198/ptvf.v4i2.28758

Saliman, T., Marta, R. F., \& Wahjudi, S. (2021). Interaksi keluarga dan kelompok sebaya menstimulasi strategi pengambilan keputusan berkuliah sembari bekerja. Jurnal Manajemen Komunikasi, 5(2), 176. https://doi.org/10.24198/jmk.v5i2.28404

Sampurno, M. B. T., Kusumandyoko, T. C., \& Islam, M. A. (2020). Budaya Media Sosial, Edukasi 
Masyarakat, dan Pandemi COVID-19. SALAM: Jurnal Sosial Dan Budaya Syar-I, 7(5). https://doi.org/10.15408/sjsbs.v7i5.15210

Septiarysa, L., Marta, R. F., \& Agung, H. (2021). Anotasi Rasa Empati selama Pandemi COVID-19 pada Konten Digital Pariwara Youtube Rosalia Indah. Jurnal Komunikasi Profesional, 5(5), 451-468. https://doi.org/https://doi.org/10.25139/jkp.v5i5.4125

Siahaan, M. (2020). Dampak Pandemi Covid-19 Terhadap Dunia Pendidikan. Jurnal Kajian Ilmiah, 1(1), 73-80. https://doi.org/10.31599/jki.v1i1.265

Supriadi, O. (2017). The Influence of Principal's Communication Skils and Quality of Leadership on Teachers' Job Satisfaction. Journal of Education and Practice, 8(29), 1-13.

Susilo, A., Rumende, C. M., Pitoyo, C. W., Santoso, W. D., Yulianti, M., Herikurniawan, H., Sinto, R., Singh, G., Nainggolan, L., Nelwan, E. J., Chen, L. K., Widhani, A., Wijaya, E., Wicaksana, B., Maksum, M., Annisa, F., Jasirwan, C. O. M., \& Yunihastuti, E. (2020). Coronavirus Disease 2019: Tinjauan Literatur Terkini. Jurnal Penyakit Dalam Indonesia.

Thompson, T. (2014). Cultivation Theory. Encyclopedia of Health Communication, 56, 83-90. https://doi.org/10.4135/9781483346427.n106

Utama, R., Bagus, I. G., Dhyana, U., \& Bali, P. (2021). Skala Pengukuran Dan Instrumen Penelitian (Sugiyono).Pdf. 2021(January 2016).

Widi, R. E. (2011). Uji Validitas dan Reliabilitas dalam Penelitian Epidemiologi Kedokteran Gigi. Stomatognatic (J.K.G. Unej), 8(1), 27-34.

Yudhaswara, R. K., \& Hidayat, D. (2021). Deskripsi Pengalaman Perilaku Selektif Memilih Informasi Di Masa Pandemi Covid-19 Pada Media Massa Televisi Description of Selective Behavioral Experience of Choosing Covid-19Information in Mass Media Television. Jurnal Penelitian Komunikasi Dan Opini Publik, 25(1), 61-73.

Yusriyah, K., Fatoni, A., \& Mansyur, M. A. (2020). Communication Networks Analysis on Information Dissemination of the Moving of Capital City From Jakarta to East Kalimantan. ASPIRATION Journal.

Zebuah, A. J. (2018). Analisis Identitas Merek, Loyalitas Merek, Citra Merek, dan Kepercayaan Merek Toyota. Jurnal Manajemen Pemasaran. https://doi.org/10.9744/pemasaran.12.2.61-68 